\title{
Peningkatan Prestasi Belajar Matematika melalui Media Puzzle Siswa Kelas I SD
}

\author{
Kasri $^{(1)}$ \\ ${ }^{1}$ SDN 4 Watuagung-Watulimo Trenggalek \\ Email: ${ }^{1}$ kasri@gmail.com, \\ DOI: https://doi.org/10.28926/riset_konseptual.v2i3.69
}

\begin{abstract}
ABSTRAK
Matematika merupakan ilmu universal yang mendasari perkembangan teknologi modern, mempunyai peran penting dalam berbagai disiplin dan memajukan daya pikir manusia, membekali peserta didik dengan kemampuan berpikir logis, analitis, sistematis, kritis, kreatif serta kemampuan bekerja sama. Penelitian ini bertujuan memperoleh gambaran yang objektif pembelajaran menggunakan media puzzle pada materi penjumlahan dan pengurangan Matematika bagi Siswa Kelas I Semester I Tahun Pelajaran 2017/2018 di SDN 4 Watuagung Kecamatan Watulimo Kabupaten Trenggalek dengan subjek 12 siswa. Hasil penelitian menunjukkan bahwa penerapan pembelajaran dengan menggunakan media puzzle pada akhir siklus I mendapatkan hasil $75 \%$, sedangkan pada akhir siklus II mencapai $90 \%$. Dengan demikian ada kenaikan sebesar 15\%. Terjadi Peningkatan Prestasi Belajar Matematika Materi Penjumlahan dan Pengurangan dengan Media Puzzle bagi Siswa Kelas I Semester I Tahun Pelajaran 2017/2018 di SDN 4 Watuagung Kecamatan Watulimo Kabupaten Trenggalek.
\end{abstract}

Kata kunci: prestasi belajar, matematika, puzzle,

\section{PENDAHULUAN}

Pendidikan nasional yang berdasarkan Pancasila dan UUD 1945 berfungsi mengembangkan kemampuan dan membentuk watak serta peradaban bangsa yang bermartabat dalam rangka mencerdaskan kehidupan bangsa, bertujuan untuk mengembangkan potensi peserta didik agar menjadi manusia beriman dan bertaqwa kepada Tuhan Yang Maha Esa, berakhlak mulia, sehat, berilmu, cakap, kreatif, mandiri, dan menjadi warga negara yang demokratis serta bertanggung jawab. Implementasi UU No. 20 tahun 2003 tentang Sistem Pendidikan Nasional dijabarkan ke dalam sejumlah peraturan antara lain Peraturan Pemerintah No. 19 tahun 2005 tentang Standar Nasional Pendidikan yang mencakup 8 standar nasional pendidikan, yaitu standar isi, proses, kompetensi lulusan, pendidik dan tenaga kependidikan, sarana dan prasarana, pengelolaan, pembiayaan, dan penilaian pendidikan.

Matematika merupakan ilmu universal yang mendasari perkembangan teknologi modern, mempunyai peran penting dalam berbagai disiplin dan memajukan daya pikir manusia. Mata pelajaran Matematika perlu diberikan kepada semua peserta didik mulai dari SD untuk membekali peserta didik dengan kemampuan berpikir logis, analitis, sistematis, kritis, kreatif serta kemampuan bekerja sama. Kompetensi tersebut diperlukan agar peserta didik dapat memiliki kemampuan memperoleh, mengelola, dan memanfaatkan informasi untuk bertahan hidup pada keadaan yang selalu berubah, tidak pasti, dan kompetitif. Konsep-konsep dasar Matematika hendaknya dipahami siswa dengan baik. Seperti halnya pada aspek bilangan, hendaknya konsep pecahan dipahami dengan baik sebelum siswa dilibatkan dengan operasi aritmatika.

Realita yang ada, sering kita jumpai anak salah dalam membaca dan menulis pecahan. Jika membaca dan menulis saja salah, tentunya pemahaman tentang konsep pecahan menjadi lebih parah. Keadaan tersebut dapat terjadi karena beberapa faktor, yang salah satunya adalah media pembelajaran atau tidak tersedianya alat peraga. Selama ini masih banyak dijumpai pembelajaran Matematika yang sifatnya verbal dan prosedural. Dalam pembelajaran Matematika siswa nampak pasif dan menerima 
pengetahuan sesuai dengan yang diberikan guru. Hal ini berdampak pada lemahnya siswa dalam memahami konsep-konsep dasar Matematika.

Realita Siswa Kelas I Semester I Tahun Pelajaran 2017/2018 di SDN 4 Watuagung Kecamatan Watulimo Kabupaten Trenggalek.materi disampaikan dengan menerapkan metode ceramah bervariasi. Hasil tes menunjukkan siswa tuntas sebanyak 7 siswa (58\%). Sedangkan siswa yang tidak tuntas mencapai 5 siswa (42\%). Sehubungan dengan tersebut perlu perapan pembelajaran inovatif, yakni penggunaan puzzle sebagai media dalam pembelajaran.

Prestasi adalah "Hasil yang telah dicapai dari apa yang telah dilakukan, dikerjakan, dan sebagainya". Sedangkan pengertian prestasi belajar secara utuh: "Penguasaan pengetahuan atau ketrampilan yang dikembangkan oleh mata pelajaran, lazimnya ditunjukkan dengan nilai test atau angka nilai yang ditunjukkan oleh guru" (Moeliono, 1990:700). Prestasi belajar sesuai dengan batasan yang ada di atas, merupakan hasil yang telah dicapai oleh siswa setelah melakukan suatu kegiatan belajar, yang wujudnya adalah angka atau nilai. Hilgard dan Bower, belajar berhubungan dengan perubahan tingkah laku seseorang terhadap suatu situasi tertentu yang disebabkan oleh pengalamannya yang berulang-ulang dalam situasi itu, dimana perubahan tingkah laku itu tidak dapat dijelaskan atas dasar kecenderungan respon pembawaan, kematangan atau keadaan-keadaan sesaat seseorang (misalnya kelelahan, pengaruh obat, dan sebagainya (Depdikbud, 2003:3)

Pendapat lain, Morgan mengatakan bahwa "Belajar adalah setiap perubahan yang relatif menetap dalam tingkah laku yang terjadi sebagai suatu hasil dari latihan atau pengalaman" (Depdiknas, 2003:3). Pendapat Morgan selaras dengan pendapat yang pertama, di mana belajar adalah perubahan yang relatif menetap dan bertumpu pada latihan dan pengalaman. Gagne, belajar terjadi apabila suatu situasi stimulus bersama dengan isi ingatan mempengaruhi pelajar sedemikian rupa sehingga perbuatannya (performancenya) berubah dari waktu sebelum ia mengalami situasi itu ke waktu sesudah ia mengalami situasi tadi (Depdiknas, 2003:3). Pendapat Gagne berkaitan erat dengan adanya stimulus atau rangsangan. Bahwa belajar dapat terjadi apabila pada diri seseorang terdapat suatu stimulus atau rangsangan. Rangsangan tersebut akan berupaya untuk merubah diri manusia. Stimulus akan sangat mempengaruhi manusia, sehingga timbul respon untuk merubah suatu situasi ke dalam situasi baru.

Matematika merupakan suatu bahan kajian yang memiliki objek abstrak dan dibangun melalui proses penalaran deduktif, yaitu kebenaran suatu konsep diperoleh sebagai akibat logis dari kebenaran sebelumnya sudah diterima, sehingga keterkaitan antara konsep dalam Matematika bersifat sangat kuat dan jelas. (Dinas Pendidikan dan Kebudayaan, 2004:2). Mata pelajaran Matematika, merupakan mata pelajaran yang dipelajari dengan berangkat dari hukum yang telah diakui kebenarannya. Mata pelajaran ini bersifat pasti. Untuk itu dikatakan bahwa pola pikir matematika adalah pola pikir deduktif, yakni membentuk konsep berdasarkan kebenaran yang sebelumnya sudah diterima. Fungsi Matematika mengembangkan kemampuan bernalar melalui kegiatan penyelidikan, eksplorasi dan eksperimen, sebagai alat pemecahan masalah melalui pola pikir dan model Matematika serta sebagai alat komunikasi melalui simbol, tabel, grafik, diagram, dalam menjelaskan gagasan. Tujuan dari mata pelajaran Matematika yang lain adalah sebagai berikut: "Melatih cara berfikir secara sistematis, logis, kritis, kreatif dan konsisten" (Dinas Pendidikan dan Kebudayaan, 2004:2).

Kata puzzle berasal dari bahasa Inggris yang berarti teka-teki atau bongkar pasang, media puzzle merupakan media sederhana yang dimainkan dengan bongkar pasang. Berdasarkan pengertian tentang media puzzle, maka dapat disimpulkan bahwa media puzzle merupakan alat permainan edukatif yang dapat merangsang kemampuan matematika anak, yang dimainkan dengan cara membongkar pasang kepingan puzzle berdasarkan pasangannya (Misbach, 2007:37). Manfaat media puzzle dalam pembelajaran meningkatkan keterampilan kognitif keterampilan kognitif berhubungan dengan kemampuan untuk belajar dan memecahkan masalah. Melalui 
Vol. 2 No. 3, Juli 2018;

puzzle, anak-anak akan mencoba memecahkan masalah yaitu menyusun gambar menjadi utuh, mengembangkan kemampuan kognitifnya dengan cara mencoba menyesuaikan bentuk, menyesuaikan warna, atau logika, meningkatkan keterampilan motorik halus, melatih kemampuan nalar dan daya ingat dan konsentrasi, melatih kesabaran, pengetahuan melalui puzzle, dan meningkatkan keterampilan sosial (Shoimin, 2014:78).

Langkah-langkah penggunaan media puzzle guru membuat organisasi konsep dari materi pembelajaran yang dipelajari, siswa dibagi menjadi kelompok-kelompok kecil terdiri dari 4-5 siswa, masing-masing kelompok dibagikan bahan ajar dan organisasi konsep yang belum dilengkapi, siswa diberi penjelasan mengenai kegiatan belajar yang akan dilakukan. Tugas masing-masing kelompok adalah melengkapi bagian-bagian bagian organisasi konsep yang masih kosong dengan media sehingga menjadi organisasi konsep yang lengkap dan utuh, kegiatan melengkapi peta konsep. Kelompok yang paling cepat memasangkan kartu konsep secara tepat mendapatkan skor paling tinggi, setelah semua organisasi konsep berhasil dilengkapi guru kemudian memberikan penjelasan dari masing-masing konsep, dan guru menyimpulkan materi pembelajaran (Shoimin, 2014:79).

\section{METODE}

Penelitian ini menggunakan Penelitian Tindakan Kelas (PTK) yang merupakan suatu penelitian tindakan dalam bidang Pendidikan yang bertujuan untuk memperbaiki atau meningkatkan mutu pembelajaran di kelas. Penelitian Tindakan Kelas merupakan suatu bentuk penelitian yang bersifat reflektif dengan melakukan tindakan-tindakan tertentu agar dapat memperbaiki atau meningkatkan praktek pembelajaran di kelas secara proposional. Penelitian tindakan kelas ini dilaksanakan dalam empat tahap, yaitu (1) tahap perencanaan (2) tahap pelaksanaan (3) tahap pengamatan, dan (4) tahap refleksi. Subyek penelitian adalah siswa - siswi kelas I SDN 4 Watuagung Kecamatan Watulimo Kabupaten Trenggalek Tahun Pelajaran 2017/2018, yang berjumlah 12 siswa, terdiri dari 7 siswa laki-laki dan 5 siswa perempuan.

\section{Rancangan Penelitian}

Penelitian menggunakan Penelitian Tindakan Kelas. Suatu pencermatan terhadap kegiatan belajar yang berupa sebuah tindakan, yang sengaja dimunculkan dan terjadi dalam sebuah kelas secara bersama untuk meningkatkan situasi pembelajaran yang menjadi tanggung jawabnya (Yanto, 2013:21). Penelitian tindakan kelas ini dilakukan selama 3 bulan, yakni pada bulan Agustus 2017 sampai dengan Oktober 2017, dilakukan dalam 4 yaitu tahapan perencanaan, tahap tindakan, tahap pengamatan, dan tahap refleksi. Keempat tahapan tersebut saling berkaitan antara tahap sebelum dan sesudahnya.

\section{Perencanaan}

Tahap ini merencanakan kegiatan pembelajaran seperti menyiapkan silabus, menyiapkan RPP, menyiapkan LKS, menyiapkan media pembelajaran, menyiapkan format pengamatan, menyiapkan tes akhir

\section{Pelaksanaan Tindakan}

Pada tahap ini, pelaksanaan dilakukan dengan menyesuaikan dengan model pembelajaran puzzle, membuat organisasi konsep dari materi yang dipelajari, siswa dibagi menjadi kelompok-kelompok kecil terdiri dari 4-5 siswa, masing-masing kelompok dibagikan bahan ajar dan organisasi konsep yang belum dilengkapi, siswa diberi penjelasan mengenai kegiatan belajar yang akan dilakukan, siswa mengerjakan tugas yang diberikan oleh guru, setelah semua organisasi konsep berhasil dilengkapi guru kemudian memberikan penjelasan dari masing-masing konsep, dan guru menyimpulkan materi pembelajaran. 
Vol. 2 No. 3, Juli 2018;

\section{Pengamatan}

Pengamatan ini berfungsi untuk melihat dan mendokumentasikan pengaruhpengaruh yang diakibatkan oleh tindakan dalam kelas. Hasil pengamatan ini merupakan dasar dilakukannya refleksi sehingga pengamatan yang dilakukan harus dapat menceritakan keadaan yang sesungguhnya. Pada tahap ini peneliti selain melaksanakan kegiatan pembelajaran juga melaksanakan pengamatan, mengingat penelitian ini tidak menggunakan kolaborator. Pengamatan difokuskan pada saat kegiatan inti pembelajaran berlangsung. Untuk melaksanakan pengamatan, maka guru menggunakan lembar pengamatan tentang keaktifan siswa, sehingga dapat diketahui banyaknya siswa aktif dan siswa yang tidak aktif.

\section{Refleksi}

Refleksi merupakan tahap akhir, dimana guru sekaligus peneliti harus dapat menemukan kelebihan dan kekurangan dari pembelajaran yang dilakukan seperti menganalisis hasil pengamatan keaktifan siswa, menganalisis hasil tes akhir dari pembelajaran yang baru berlangsung, dan menganalisis kelebihan dan kekurangan pada pembelajaran yang dilaksanakan yang selanjutnya dicari jalan keluarnya, agar pembelajaran berikutnya menjadi lebih baik.

\section{Teknik Pengumpulan Data}

Pengumpulkan data dilakukan dengan menggunakan teknik-teknik tertentu. Pada penelitian ini, teknik pengumpulan data yang dipergunakan ada dua macam, yakni tes dan non tes. Teknik tes merupakan teknik pengumpulan data yang menggunakan instrument lembar soal tes akhir. Sedangkan teknik non tes dipergunakan dengan instrument yang berwujud teknik non tes.

\section{Teknik Analisis Data}

Penelitian menggunakan teknik analisis data yang relevan. Sedangkan teknik analisa data yang relevan adalah teknik analisa data statistic. Untuk analisa data secara detail, secara sederhana dengan mencari nilai rata-rata kelas, prosentase ketuntasan belajar, dan mengetahui kemampuan guru dalam melaksanakan pembelajaran dengan media puzzle dilakukan dengan lembar pengamatan guru.

\section{HASIL}

Penelitian untuk mengetahu peningkatan belajar Matematika, berdasarkan pengamatan deskripsi pra siklus mengalami rendahnya prestasi belajar siswa yang dapat dilihat dari nilai rata-rata dan tingkat ketuntasan belajar siswa. KKM sebesar 70 , siswa tidak tuntas sebanyak 7 siswa (58\%). Sedangkan siswa yang tuntas mencapai 5 siswa (42\%). Nilai rata-rata yang dapat dicapai oleh siswa adalah 76 . Berdasarkan kategorinya, siswa yang mencapai nilai istimewa sebanyak 2 siswa (17\%), siswa yang mencapai nilai sangat memuaskan sebanyak 2 siswa (17\%), siswa yang mencapai nilai memuaskan sebanyak 2 siswa (17\%), siswa yang mencapai nilai cukup sebanyak 1 siswa (8\%), dan siswa yang mencapai nilai kurang sebanyak 5 siswa (42\%). Nilai yang sering muncul atau modusnya adalah nilai kurang dari 70 sebanyak 5 siswa (42\%). Terfleksi siswa terlihat tenang dan diam, tetapi pada kenyataannya siswa belum dapat menguasai isi cerita dengan baik, guru belum menggunakan media sama sekali. Dengan demikian daya tarik cerita juga sangat kurang, dan metode pembelajaran yang diterapkan kurang menuntut adanya partisipasi siswa, sehingga pembelajaran berpusat pada guru saja (Teacher Centered), dan perlu tindakan pembelajaran siklus 1.

Paparan kegiatan siklus I dengan menerapkan model pembelajaran media puzzle KKM sebesar 70, siswa tuntas sebanyak 7 siswa (58\%). Sedangkan siswa yang tida tuntas mencapai 5 siswa (42\%). Nilai rata-rata yang dapat dicapai oleh siswa adalah 76. Berdasarkan kategorinya, siswa yang mencapai nilai istimewa sebanyak 2 siswa (17\%), siswa yang mencapai nilai sangat memuaskan sebanyak 2 siswa (17\%), 
siswa yang mencapai nilai memuaskan sebanyak 3 siswa (24\%), siswa yang mencapai nilai cukup sebanyak 1 siswa (8\%), dan siswa yang mencapai nilai kurang sebanyak 5 siswa (42\%). Nilai yang sering muncul atau modusnya adalah nilai 60 sebanyak 5 siswa (42\%). Hasil paparan pertemuan ke dua siklus I KKM sebesar 70, siswa tuntas sebanyak 9 siswa (75\%). Sedangkan siswa yang tidak tuntas mencapai 3 siswa (25\%). Nilai rata-rata yang dapat dicapai oleh siswa adalah 81. Berdasarkan kategorinya, siswa yang mencapai nilai istimewa sebanyak 3 siswa (25\%), siswa yang mencapai nilai sangat memuaskan sebanyak 2 siswa (17\%), siswa yang mencapai nilai memuaskan sebanyak 3 siswa (25\%), siswa yang mencapai nilai cukup sebanyak 1 siswa (8\%), dan siswa yang mencapai nilai kurang sebanyak 3 siswa (25\%). Nilai yang sering muncul adalah 100.80 , dan 60 , dimana masing-masing muncul sebanyak 3 kali (25\%). Refleksi guru sudah menggunakan media dalam pembelajaran, tetapi belum maksimal, siswa masih malu dan ragu untuk menyampaikan ide dan gagasannya.

Hasil deskripsi siklus II tetap berpacu pada KKM sebesar 70, siswa tuntas sebanyak 12 siswa (100\%). Nilai rata-rata yang dapat dicapai oleh siswa adalah 88 . Berdasarkan kategorinya, siswa yang mencapai nilai istimewa sebanyak 6 siswa (50\%), siswa yang mencapai nilai sangat memuaskan sebanyak 1 siswa (8\%), siswa yang mencapai nilai memuaskan sebanyak 2 siswa (17\%), siswa yang mencapai nilai cukup sebanyak 3 siswa (25\%), dan siswa yang mencapai nilai kurang sebanyak 0 siswa (0\%). Nilai yang sering muncul adalah 100, sebanyak 6 siswa (50\%). Refleksi guru sudah menggunakan media yang memadai pada saat melaksanakan pembelajaran, siswa sudah dapat mengemukakan ide dan gagasannya dengan lancer, dan prestasi belajar siswa susah maksimal yang ditunjukkan dengan tingkat ketuntasan belajar yang mencapai $100 \%$.

\section{PEMBAHASAN}

Hasil perbandingan sesuai dengan tabel di atas, dapat disampaikan sebagai berikiut nanyaknya siswa tuntas pada siklus I pertemuan 1 sebanyak 7 siswa (58\%), banyaknya siswa tuntas pada siklus II sebanyak 12 siswa (100\%). Dengan demikian ada kenaikan sebanyak 5 siswa (42\%) dari siklus awal siklus I ke akhir siklus II. Nilai rata-rata kelas pada awal siklus I adalah 77 dan pada akhir siklus II adalah 88. Terjadi kenaikan sebesar 11 poin. Rekap penerapan pembelajaran dengan media puzzle diambil dari pelaksanaan model pembelajaran ini oleh guru pada akhir siklus I mendapatkan hasil 75\%, sedangkan pada akhir siklus II mencapai 90\%. Dengan demikian ada kenaikan sebesar $15 \%$.

Hasil penelitian terjadi Peningkatan Prestasi Belajar Matematika Materi Penjumlahan dan Pengurangan dengan Media Puzzle bagi siswa Kelas I Semester I Tahun Pelajaran 2017/2018 di SDN 4 Watuagung Kecamatan Watulimo Kabupaten Trenggalek. Terjadi peningkatan penerapan pembelajaran dengan menggunakan media puzzle pada materi penjumlahan dan pengurangan bagi siswa Kelas I Semester I Tahun Pelajaran 2017/2018 di SDN 4 Watuagung Kecamatan Watulimo Kabupaten Trenggalek. Sesuai dengan hasil penelitian, maka dapat dipastikan dan dibuktikan bahwa penggunaan media puzzle dalam pembelajaran sangat memotivasi siswa, sehingga siswa dapat meningkatkan prestasi belajarnya. Untuk itu pembelajaran ini dapat direkomendasikan sebagai salah satu terobosan yang dapat dilakukan oleh guru dalam melaksanakan kegiatan pembelajaran yang berkjualitas.

\section{KESIMPULAN}

Simpulan yang diambil dari penelitian banyaknya siswa tuntas pada siklus I pertemuan 1 sebanyak 7 siswa (58\%). Banyaknya siswa tuntas pada siklus II sebanyak 12 siswa (100\%). Nilai rata-rata kelas pada awal siklus I adalah 77 dan pada akhir siklus II adalah 88. Terjadi kenaikan sebesar 11 poin. Penerapan pembelajaran dengan menggunakan media puzzle pada akhir siklus I mendapatkan hasil $75 \%$, sedangkan pada akhir siklus II mencapai 90\%. Dengan demikian ada kenaikan sebesar $15 \%$. Dengan demikian simpulan yang dapat diperoleh adalah terjadi 
Vol. 2 No. 3, Juli 2018;

Peningkatan Prestasi Belajar Matematika Materi Penjumlahan dan Pengurangan dengan Media Puzzle bagi siswa Kelas I Semester I Tahun Pelajaran 2017/2018 di SDN 4 Watuagung Kecamatan Watulimo Kabupaten Trenggalek. Terjadi peningkatan penerapan pembelajaran dengan ,enggunakan media puzzle pada materi penjumlahan dan pengurangan bagi Siswa Kelas I Semester I Tahun Pelajaran 2017/2018 di SDN 4 Watuagung Kecamatan Watulimo Kabupaten Trenggalek.

\section{SARAN}

Sesuai dengaan hasil penelitian yang diperoleh, maka saran yang dapat disampaikan adalah kepada siswa diharapkan dapat meningkatkan rasa tanggung jawabnya, sehingga mempunyai kemauan dan semangat belajar yang tinggi. Tentunya dengan kondisi yang demikian dapat meningkatkan prestasi belajarnya. Kepada guru diharapkan juga mempunyai semangat seperti siswa, bertanggung jawab terhadap tugasnya, sehingga pembelajaran dapat berlangsung dengan menyenangkan dan dapat bermakna, baik bagi guru maupun bagi siswa. Kepada kepala sekolah diharapkan dapat memotivasi guru dengan baik, sehingga guru memperoleh motivasi ekstrinsik untuk meningkatkan motivasi intrinsik yang ada pada dirinya. Menyatunya motivasi ekstrinsik dan intrinsik akan memberikan kekuatan yang sangat besar untuk sama-sama melaksanakan tanggung jawabnya.

\section{DAFTAR RUJUKAN}

Arikunto, Suharsimi. 2011. Penelitian Tindakan Kelas. Jakarta. BumiAksara Moeliono Anton. 1990. Kamus Besar Bahasa Indonesia. Jakarta: Balai Pustaka Patmonodewo. 2007. Pendidikan Anak Pra Sekolah. Jakarta:Rineka Cipta

Shoimin, Aris. 2014. 68 Model Pembelajaran Inovatif dalam Kurikulum 2013. Yogyakarta:Ar-Ruzz Media 2003. Psikologi Belajar. Depdiknas. 2003. Undang-Undang RI No. 20 Tahun 2003 Tentang Sistem Pendidikan Nasional. Jakarta: Depdiknas 2004. Kurikulum Pendidkan Dasar (GBPP SD). Depdikbud 